\title{
Epigenetic changes during hematopoietic cell granulocytic differentiation - comparative analysis of primary CD34+ cells, KG1 myeloid cells and mature neutrophils
}

\author{
Rūta Navakauskienè $\dot{1}^{1,2^{*}}$, Veronika V Borutinskaitè ${ }^{1}$, Gražina Treigytè ${ }^{1}$, Jūratė Savickienè ${ }^{1}$, Dalius Matuzevičius ${ }^{3,4}$,
} Dalius Navakauskas ${ }^{4}$ and Karl-Eric Magnusson ${ }^{5}$

\begin{abstract}
Background: Epigenetic regulation is known to affect gene expression, and recent research shows that aberrant DNA methylation patterning and histone modifications may play a role in leukemogenesis. In order to highlight the co-operation of epigenetic mechanisms acting during the latter process it is important to clarify their potential as biomarkers of granulocytic differentiation.

Results: In this study we investigated epigenetic alterations in human hematopoietic cells at a distinct differentiation stages: primary hematopoietic CD34+ cells, KG1 myeloid leukemic cells, whose development is stopped at early stage of differentiation, and mature neutrophils. We focused on the epigenetic status of cell cycle regulating $(p 15, p 16)$ and differentiation related $(E$-cadherin and $R A R \beta)$ genes. We found that the methylation level in promoter regions of some of these genes was considerably higher in KG1 cells and lower in CD34+ cells and human neutrophils. As examined and evaluated by computer-assisted methods, histone $\mathrm{H} 3$ and $\mathrm{H} 4$ modifications, i.e. H3K4Me3, H3K9Ac, H3K9Ac/S10Ph and H4 hyperAc, were similar in CD34+ cells and human mature neutrophils. By contrast, in the KG1 cells, histone $\mathrm{H} 3$ and $\mathrm{H} 4$ modifications were quite high and increased after induction of granulocytic differentiation with the HDAC inhibitor phenyl butyrate.

Conclusions: We found the methylation status of the examined gene promoters and histone modifications to be characteristically associated with the hematopoietic cell progenitor state, induced to differentiate myeloid KG1 cells and normal blood neutrophils. This could be achieved through epigenetic regulation of E-cadherin, p15, p16 and RARß genes expression caused by DNA methylation/demethylation, core and linker histones distribution in stem hematopoietic cells, induced to differentiation KG1 cells and mature human neutrophils, as well as the histone modifications H3K4Me3, H3K9Ac, H3K9Ac/S10Ph and H4 hyperAc in relation to hematopoietic cell differentiation to granulocyte. These findings also suggest them as potentially important biomarkers of hematopoietic cell granulocytic differentiation and could be valuable for leukemia induced differentiation therapy.
\end{abstract}

Keywords: CD34+ cells, Neutrophils, KG1 cells, Histones, Gene methylation/demethylation

\footnotetext{
* Correspondence: ruta.navakauskiene@bchi.vu.lt

'Department of Molecular Cell Biology, Institute of Biochemistry, Vilnius University, LT-08662 Vilnius, Lithuania

${ }^{2}$ Department of Chemistry and Bioengineering, Faculty of Fundamental Sciences, Vilnius Gediminas Technical University, LT-10223 Vilnius, Lithuania Full list of author information is available at the end of the article
} 


\section{Background}

Epigenetic changes are reversible and interfere with many key biological functions, including regulation of gene expression through chromatin remodeling, DNA methylation/demethylation and microRNA. Moreover, many of these changes have been linked to the pathogenesis of human diseases and cancers [1].

Aberrant DNA methylation is frequent in myeloid malignancies, particularly in the myelodysplastic syndrome (MDS) and acute myelogenous leukemia (AML). Promoter CpG methylation correlates with silencing of tumor-suppressor genes in specific pathways, which are also the targets for mutations or other mechanisms of inactivation [2]. Epigenetic contributions to myeloid pathogenesis appear more complex and deregulations occur at multiple disease stages. Accordingly, therapeutics directed towards epigenetic mechanisms, involving for instance DNA methyltransferase (DNMT) and histone deacetylase (HDAC) inhibitors, have had some clinical success when applied to MDS and AML [2-6].

DNA methylation and histone tail modifications are characteristic epigenetic signatures in physiologic development that become abnormal in neoplasia. Thus, silencing of critical genes by DNA methylation or histone deacetylation can contribute to leukemogenesis as an alternative to deletion or loss-of-function mutations. In AML, aberrant DNA methylation has been observed in several of functionally relevant genes, such as $p 15, p 16, p 73$, E-cadherin, ID 4 and $R A R \beta 2$. It was shown for instance by Hopfer and coauthors [7] that associations between aberrant promoter methylation and DNMT expression predict high-risk MDS for all lineages and during erythropoiesis. Moreover, hypermethylation of $p 15, p 16, p 73$, survivin, CHK2, RAR $\beta$ and DAPK genes were associated with elevated DNMT isoform expression.

Abnormal activities of histone tail-modifying enzymes have also been seen in AML, frequently as a direct result of chromosomal translocations. It is now clear that these epigenetic changes play a significant role in development and progression of AML, and thus constitute important targets of therapy [8,9]. Interactions between histone modifications and DNA methylation are less well studied. Although genome-wide studies have suggested that there is a negative correlation between $\mathrm{H} 3 \mathrm{~K} 4 \mathrm{Me} 3$ and DNA methylation, and a positive one between H3K9Me3 and DNA methylation, insights into the understanding of these connections have just recently advanced [10-12].

Hematopoietic stem cells characteristically display self-renewal and differentiation into mature distinct hematopoietic lineages; defining the latter and understanding of the processes that control their differentiation and self-renewal or cause their malignancies are thus of great interest. Human hematopoietic progenitor CD34+ cells collected from healthy human blood,
KG1 cells representing blocked differentiation at an early stage of hematopoietic development, and mature human neutrophils can accordingly be used in epigenomic surveys. CD34+ cells provide a valuable model system where progression from quiescent to cycling to differentiated states can be linked to changes in chromatin rearrangements. Changes in histones $\mathrm{H} 3$ and $\mathrm{H} 4$ modifications being associated with chromatin activation, i.e. H3K4Me3, H3K9Ac, H3K9Ac/S10Ph and H4 hyperAc, and reactivation of methylation-silenced genes could be distinct in hematopoietic primary CD34+ cells, KG1 cells and mature neutrophils. We employed computational analyses of confocal images to evaluate such histone modifications changes in these cell populations.

We disclosed that the rates of methylation in promoter regions of genes involved in the control of differentiation (E-cadherin, RAR $\beta$ ) and cell cycle progression ( $p 15$ and p16) were considerably lower than that of unmethylation in CD34+, neutrophils and KG1 cells. As evaluated by computer-assisted methods the $\mathrm{H} 3$ and $\mathrm{H} 4$ modifications H3K4Me3, H3K9Ac, H3K9Ac/S10Ph and H4 hyperAc were similar for CD34+ cells and human mature neutrophils. The KG1 cells displayed elevated levels of those modifications with an increase after treatment with HDAC inhibitors (HDACI). To conclude, our findings could be important for identification and evaluation of new biomarkers and targets for leukemia differentiation therapy.

\section{Results and discussion}

Methylation of p15, p16, E-cadherin, and RAR $\beta$ genes in hematopoietic cells during granulocytic differentiation

Here we chose to examine the methylation status in specific promoter regions of genes involved in cell cycle regulation $(p 15, p 16)$ and granulocytic differentiation (E-cadherin and $R A R \beta)$ during hematopoietic cell development. As distinct cellular models we employed human hematopoietic progenitor CD34+ cells collected from healthy human blood, the human myeloid leukemia cell line KG1, whose development is stopped at early stage of differentiation, and mature human neutrophils.

As presented in Figure 1, the hematopoietic progenitor $\mathrm{CD} 34+$ cells and mature neutrophils (NF) presented similar demethylation levels of both cell cycle- and differentiation- regulating genes. However, there were lower $p 15$, E-cadherin, RAR beta and higher $p 16$ methylations in human neutrophils than in hematopoietic progenitor CD34+ cells. The promoters of all genes investigated were methylated in KG1 cells. Incidentally, it is known that the INK4 family of proteins p14, p15 and p16 function as cell cycle inhibitors by being involved in the inhibition of G1 phase progression. Methylation of the $p 15$ promoter is a major gene silencing mechanism in hematological malignancies, while $p 14$ and 


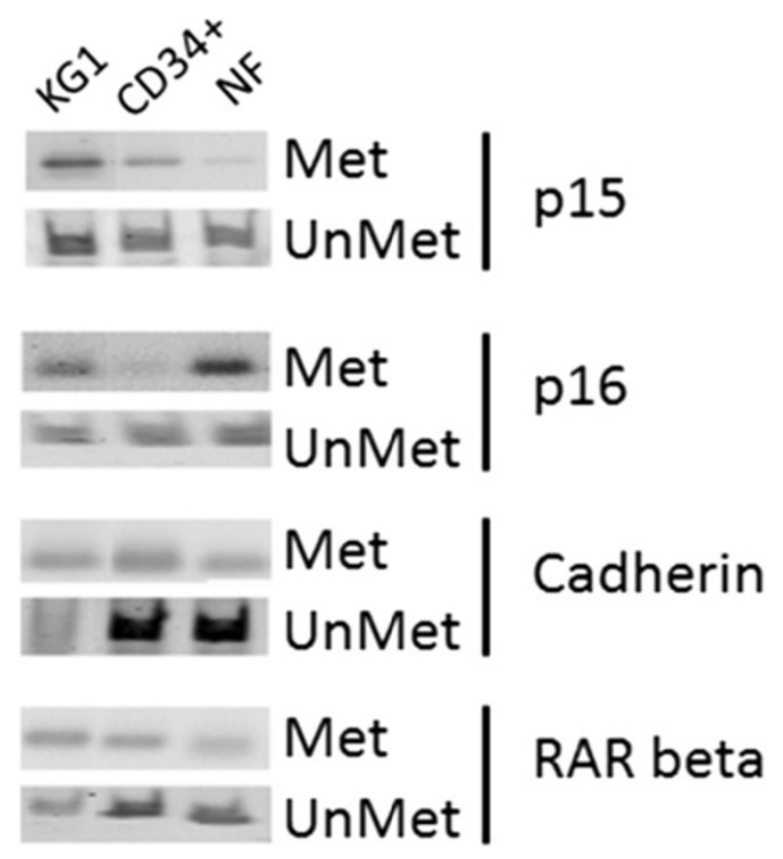

Figure $1 p 15, p 16, E$-cadherin and RAR $\beta$ gene methylation status during hematopoietic cell development. The methylation/ unmethylation status was evaluated through genomic DNA bisulfite conversion of examined gene promoter regions, as described in "Materials and Methods". The products of methylated (Met) and unmethylated (UnMet) p15, p16, E-cadherin and RAR $\beta$ were electrophoresed on $3 \%$ agarose gel, stained with ethidium bromide, and photographed. Representative images from one of three experiments showing similar results are shown.

p16 promoter methylations often occur in solid tumors, as well as in leukemia and lymphoma [13,14]. Mizuno and coworkers [15] demonstrated that DNMT genes were constitutively expressed, although at different levels, in $\mathrm{T}$ lymphocytes, monocytes, neutrophils, and normal bone marrow cells. Altered expression of DNMT in hematopoietic cells could cause an aberrant methylation/demethylation status of genes in these cells. Using methylation-specific PCR, it was observed that the $p 15$ gene was methylated in 24 of 33 (72\%) cases of patients with AML. Recently we have also shown, that the DNMT inhibitor (DNMTI) zebularine alone or in sequential combination with retinoic acid (RA) decreased expression of DNMT1 in KG1 and NB4 cells, caused partial demethylation of E-cadherin and reexpression of pan-cadherin but not the tumor suppressor p15 [16]. We have also demonstrated [17] that DNMTI RG108 changed E-cadherin promoter methylation status and the levels of the transcript and protein in NB4 cells. When promyelocytic leukemia cells were treated with RG108 and sodium-4-phenylbutyrate (PB) as single agents and in combination with RA we found [17-19] that these treatments cause increased levels of histone $\mathrm{H} 4$ acetylation and methylation of histone H3K4Me3. Both modifications represent an active chromatin state that leads to opening of chromatin structure and induces granulocytic differentiation of human promyelocytic leukemia cells.

Here, we observed that specific promoter regions of genes involved in granulocytic differentiation (E-cadherin and $R A R \beta)$ are highly unmethylated both in hematopoietic progenitor CD34+ cells and mature neutrophils (Figure 1). It is known that E-cadherin is functionally involved in the differentiation process of cells along the erythroid lineage [20], in CD34+ stem cells and in bone marrow stroma cell [21], and plays a crucial role in cell-cell aggregation during development and could promote intercellular interactions during hematopoiesis. In neutrophils certain promoter regions of E-cadherin are highly unmethylated (Figure 1), which relates to differentiation stage of hematopoietic cells.

Corn and others [22] have shown that E-cadherin was aberrantly methylated in 4 of $4(100 \%)$ leukemia cell lines, in 14 of $44(32 \%)$ acute myelogeneous leukemias, and in 18 of 33 (53\%) acute lymphoblastic leukemias. Methylation was associated with loss of specific E-cadherin RNA and protein in leukemia cell lines and primary leukemias. Following treatment with different DNMTIs like 5-aza-2' deoxycytidine [22] or zebularine [16], leukemia cell line expressed both the E-cadherin transcript and protein.

$R A R \beta$ is an RA-regulated tumor suppressor gene silenced by aberrant DNA methylation in acute promyelocytic leukemia (APL) and other human malignancies $[23,24]$. In human leukemia HL-60 and K562 cell lines $R A R \beta$ gene is silenced [25]. Moreover, using the HDACIs and DNMTIs (TSA, VPA and 5-Aza-CdR, respectively) has been shown to restore the expression of silenced $R A R \beta[26,27]$. In our study we observed that the RAR $\beta$ methylation/unmethylation ratio in KG1 cells was balanced and constitutes around 50\%, whereas in human hematopoietic progenitor cells CD34+ and mature neutrophils $R A R \beta$ promoter regions were methylated only to about $25 \%$.

Our results demonstrate that demethylations in specific promoter regions of $p 15, p 16$, E-cadherin and $R A R \beta$ are common phenomena in normal hematopoietic cells and corroborate a hypothesis that methylation of these genes occurs in leukemogenesis.

\section{Distribution of histones, histone variants and} modifications during hematopoietic cell granulocytic differentiation toward mature neutrophils

Core histones $\mathrm{H} 2 \mathrm{~A}, \mathrm{H} 2 \mathrm{~B}, \mathrm{H} 3$ and $\mathrm{H} 4$ wrap DNA and affect chromatin condensation levels through both histone and DNA modifications. The chromatin structure plays an essential role in gene regulation during cell development, proliferation, differentiation and apoptosis, 
and core histones as well as linker histone $\mathrm{H} 1$ variants could be important factors for the maintenance of stem cell pluripotency, DNA condensation and gene expression regulation [28-30]. Indeed, some of histone variants, i.e. H3.3, H2A.Z, H2A.X and macro H2A play precise roles in chromatin structure regulation [31].

In our study we examined core histone and linker histone $\mathrm{H} 1$ distributions in hematopoietic CD34+ stem cells, control and induced to granulocytic differentiation myeloid leukemia KG1 cells and mature human neutrophils. Isolated histones were fractionated in an AUT system and stained (Figure 2) or after fractionation sub-fractionated with SDS/PAGE (Figure 3). In Figure 2 we show that linker histone $\mathrm{H} 1$ expression decreased during differentiation and is in a low level in mature human neutrophils. Terme and co-workers [30] have demonstrated that $\mathrm{H} 1$ variants are differentially expressed during cell differentiation; here pluripotent cells (ES and iPS4F1) have lower levels of the histone variant $\mathrm{H} 1.0$ and higher levels of the H1.3 and H1.5 variants, whereas others, i.e. H1.2 and H1.4, did not display any significant changes.

Histone $\mathrm{H} 3$ is an important epigenetic target because of its diverse modification states. In our study we showed that H3.1 and H3.2 are slightly decreased in CD34+ and NF in comparison to KG1 cells represented differentiating hematopoietic cells (Figures 2 and 3). The histone H3 variant H3.3 level did decline only in mature human neutrophils (Figures 2 and 3), where an active gene expression was reduced. It has been shown that H3.3 containing nucleosomes are enriched in active chromatin [32]. Jin and Felsenfeld [33] have demonstrated that H3.3 may play a direct role in activation of the chicken folate receptor (FR) and $\beta$-globin genes. As shown in Figures 2 and 3 histones $\mathrm{H} 2 \mathrm{~A}$ and $\mathrm{H} 2 \mathrm{~B}$ did not exibit apparent differences in all types of examined cells. By contrast the acetylation of histones $\mathrm{H} 3$ and $\mathrm{H} 4$ was striking in KG1 cells induced to granulocytic differentiation by HDACI PB and RA [34], but not with DNMTI RG108 (Figure 2).

Our findings suggest that core histones and their variants as well as the linker histone $\mathrm{H} 1$ distribute diversely during granulocytic differentiation of hematopoietic cells and that their distribution reflects the differentiation status of hematopoietic cells.

\section{$\mathrm{H} 3$ and $\mathrm{H} 4$ modifications highlight active chromatin as being important in hematopoietic differentiation}

For evaluation of histone modifications and active chromatin formation during granulocytic differentiation we investigated the modification status of H3K4Me3, H3K9Ac, H3K9Ac/ $\mathrm{S} 10 \mathrm{Ph}$ and $\mathrm{H} 4$ hyperAc histones in human hematopoietic progenitor CD34+ cells, untreated and treated with $\mathrm{PB}$ as a HDACI or RG108 as a non-nucleoside DNMTI human myeloid leukemia KG1 cells, and mature human neutrophils.

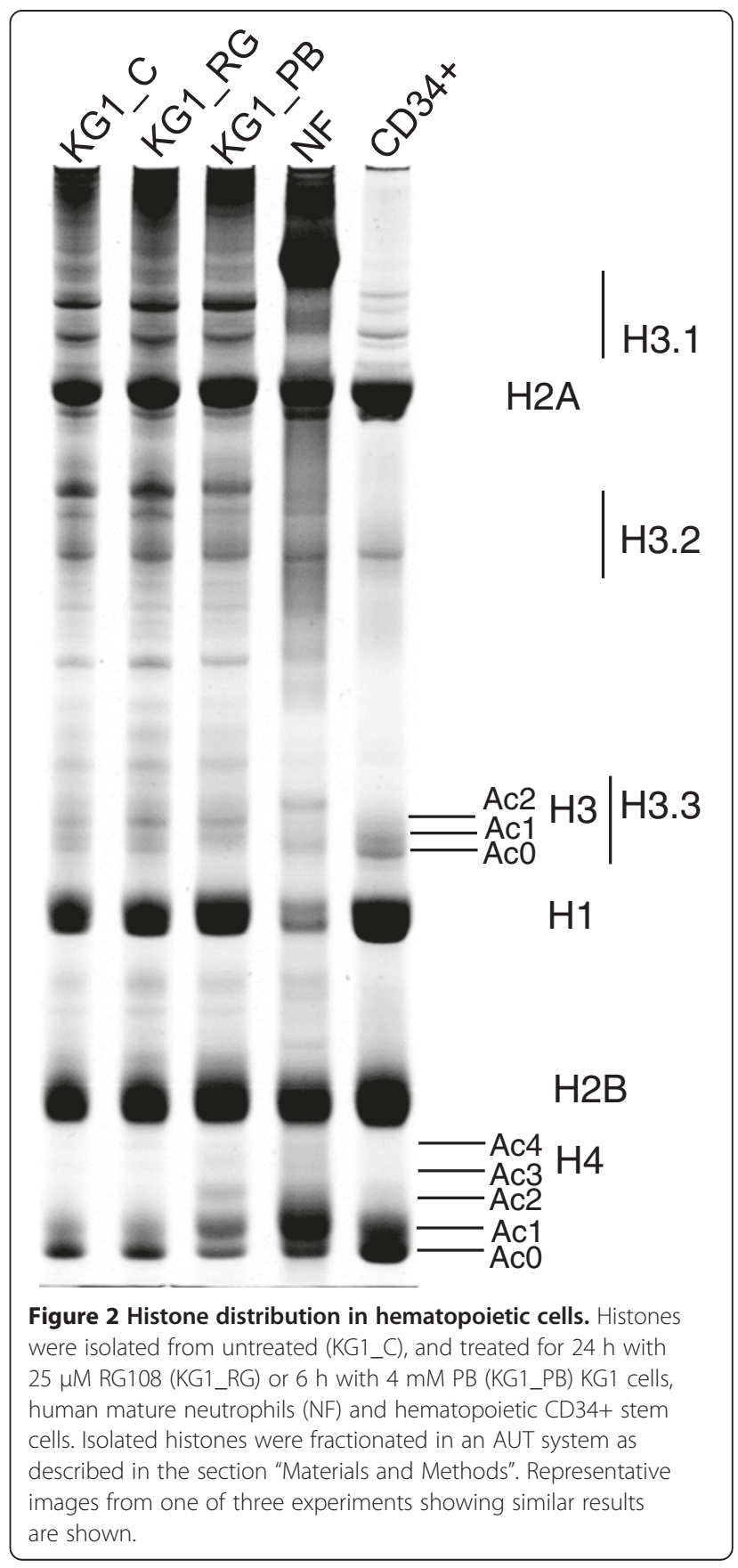

In Figures 4, 5, 6 and 7 we present confocal images of the fluorescence intensity of histones H3K4Me3 (Figure 4), H3K9Ac (Figure 5), H3K9Ac/S10Ph (Figure 6) and H4 hyperAc (Figure 7) together with ratios of the median values of the fluorescent intensities. Total fluorescence intensity for each cell type grouped by class (CD34+, KG1_C, KG1_PB, KG1_RG, NF) was used for the computation of median values. The hematopoietic progenitor CD34+ cells and neutrophils showed very similar histone modification levels (Figures 5, 6 and 7), except for $\mathrm{H} 3 \mathrm{~K} 4 \mathrm{Me} 3$; the latter is present in transcriptionally active 


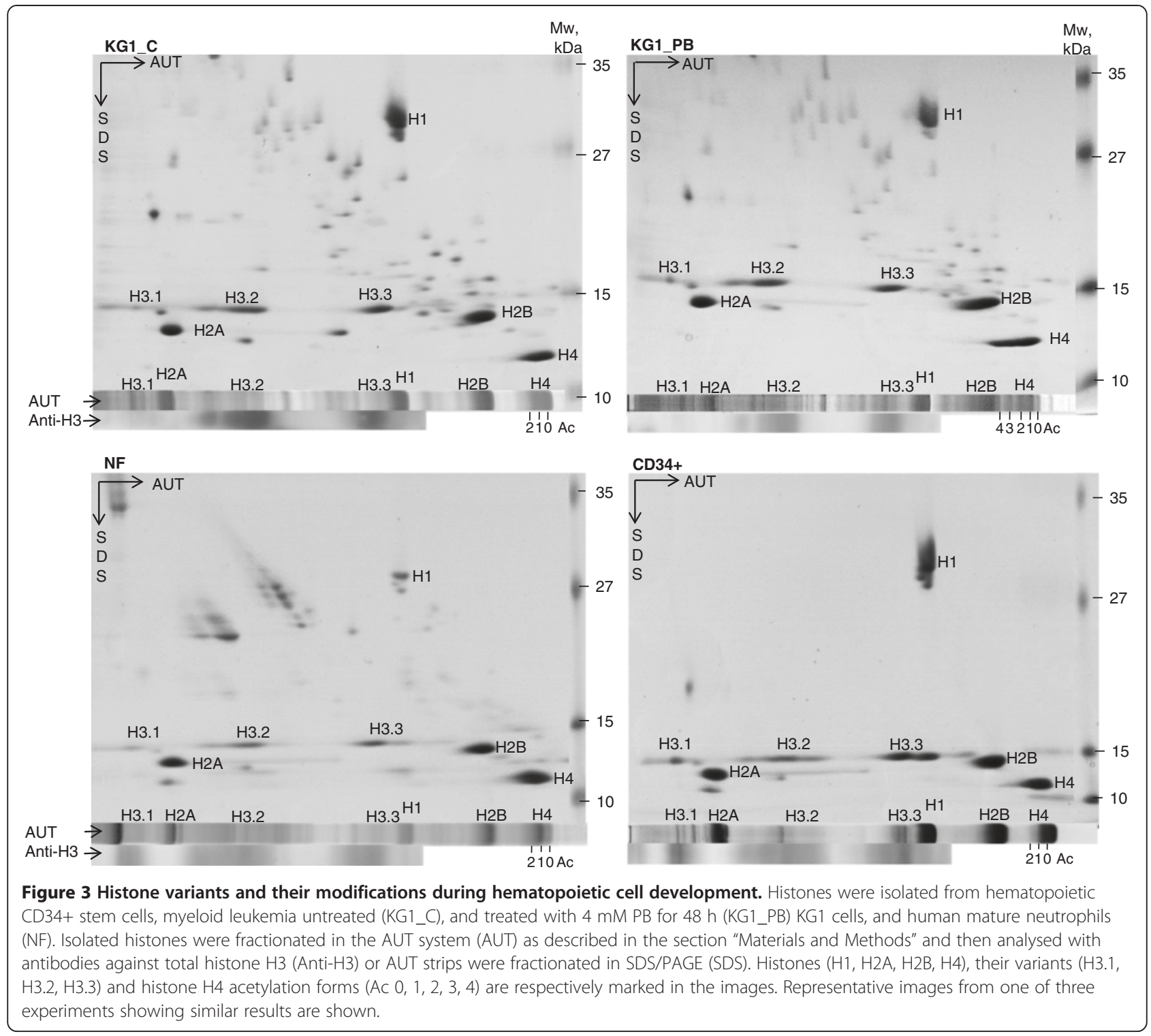

chromatin and in neutrophils its level was reduced (Figure 4). Moreover, it was diminished in control KG1 cells (Figure 4) in comparison with CD34+ cells. H3K9Me3 deregulation in AML is related preferentially to a decrease of the modifications in core promoter regions. MullerTidow and coworkers [35] have shown that a decrease in H3K4Me3 levels at CREs was associated with increased CRE-driven promoter activity in vivo in AML blasts. There are also widespread changes of H3K9Me3 levels at gene promoters in AML [35]. Paul and coworkers [36] observed that reactivation of p15INK4b expression in AML cell lines and patient blasts using 5-aza-2'-deoxycytidine (decitabine) and Trichostatin A (TSA) increased H3K4Me3 and maintained H3K27Me3 enrichment at p15INK4b. These data indicate that AML cells with p15INK4b DNA methylation have an altered histone methylation pattern compared to unmethylated samples and that these changes are reversible by epigenetic drugs.

We have demonstrated previously [16] that the DNMTI zebularine induced regional chromatin remodeling by local histone $\mathrm{H} 4$ hyperacetylation and histone H3K4 methylation in promoter sites of methylated E-cadherin and unmethylated $p 21$ in promyelocytic leukemia NB4 cells. In this study we also saw increased $\mathrm{H} 3$ and $\mathrm{H} 4$ acetylated forms both in control and in treated with HDACI and DNMTI KG1 cells. Moreover, PB as a HDACI and RG108 as a DNMTI did not induce KG1 cell differentiation albeit they changed the range of histones $\mathrm{H} 3$ and $\mathrm{H} 4$ modifications. The elucidation of the epigenetic changes in normal hematopoietic cells and myeloid leukemia cells induced to differentiate will contribute towards the clarification of the histone modifications dynamics in myeloid cell lineage development. 


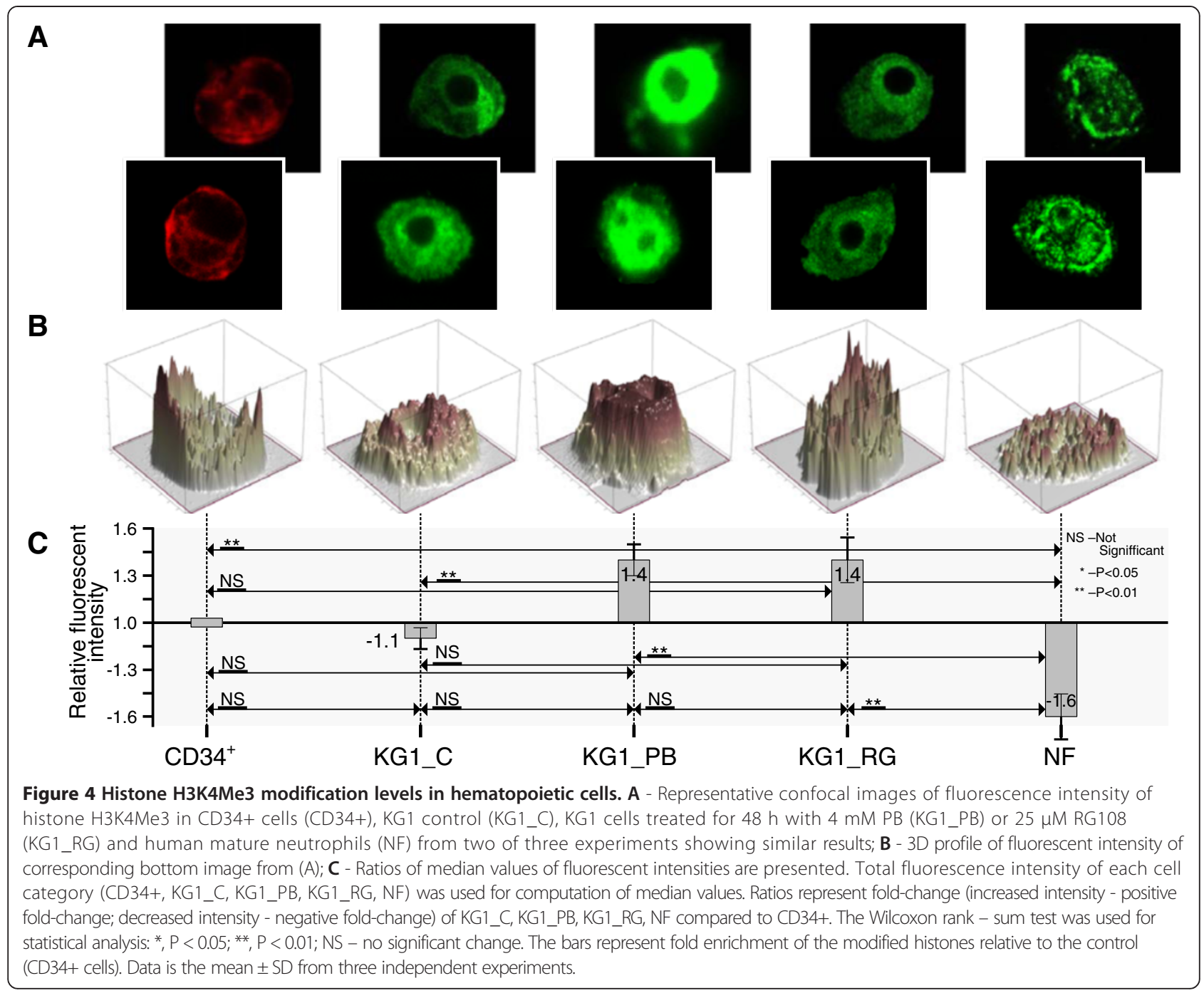

These histone modifications are capable of affecting chromatin structure and gene transcription regulation. Consequently, epigenetic modifiers can be governed in order to regulate repressed genes in leukemia cells. The evaluation of histones $\mathrm{H} 3$ and $\mathrm{H} 4$ modifications (H3K4Me3, H3K9Ac, H3K9Ac/S10Ph and H4 hyperAc) could be instrumental for finding new leukemia biomarkers on an epigenome basis.

\section{Conclusions}

Evaluation of the methylation status of specific promoter regions of $p 15, p 16, E$-cadherin and $R A R \beta$ genes, core and linker histones distribution, histones $\mathrm{H} 3$ and $\mathrm{H} 4$ modifications (H3K4Me3, H3K9Ac, H3K9Ac/S10Ph and $\mathrm{H} 4$ hyperAc) during hematopoietic cell differentiation can provide a new basis for identifying chromatin epigenetic modulators as targets in the regulation of hematopoiesis and for leukemia induced differentiation therapy.

\section{Methods}

\section{Cell culture}

The human myeloid cells KG1 were cultured in RPMI 1640 medium supplemented with $10 \%$ fetal bovine serum, $100 \mathrm{U} / \mathrm{ml}$ penicillin, and $100 \mu \mathrm{g} / \mathrm{ml}$ streptomycin (Gibco, Grand Island, NY) at $37^{\circ} \mathrm{C}$ in a humidified $5 \%$ $\mathrm{CO}_{2}$ atmosphere. In each experiment, logarithmically growing cells were seeded into $5 \mathrm{ml}$ of medium at a density $5 \times 10^{5}$ cells $/ \mathrm{ml}$. In the treatment experiments, cells were exposed to the HDACI $4 \mathrm{mM} \mathrm{PB}$ or DNMTI $25 \mu \mathrm{M}$ RG108 the time indicated.

\section{Separation of mononuclear cells from human blood}

Mononuclear cells from whole-blood samples from donors were obtained by buffy coat centrifugation from the blood bank (Linkoping University Hospital, Sweden), see also Ethics Statement. The buffy coat $(50 \mathrm{ml})$ was mixed with $1 \mathrm{vol}$ of $0.9 \% \mathrm{NaCl}$ and $2 \mathrm{vol}$ of $2 \%$ dextran in $0.9 \%$ $\mathrm{NaCl}$ and allowed the fluid separation for $40 \mathrm{~min}$ at $4^{\circ} \mathrm{C}$. 


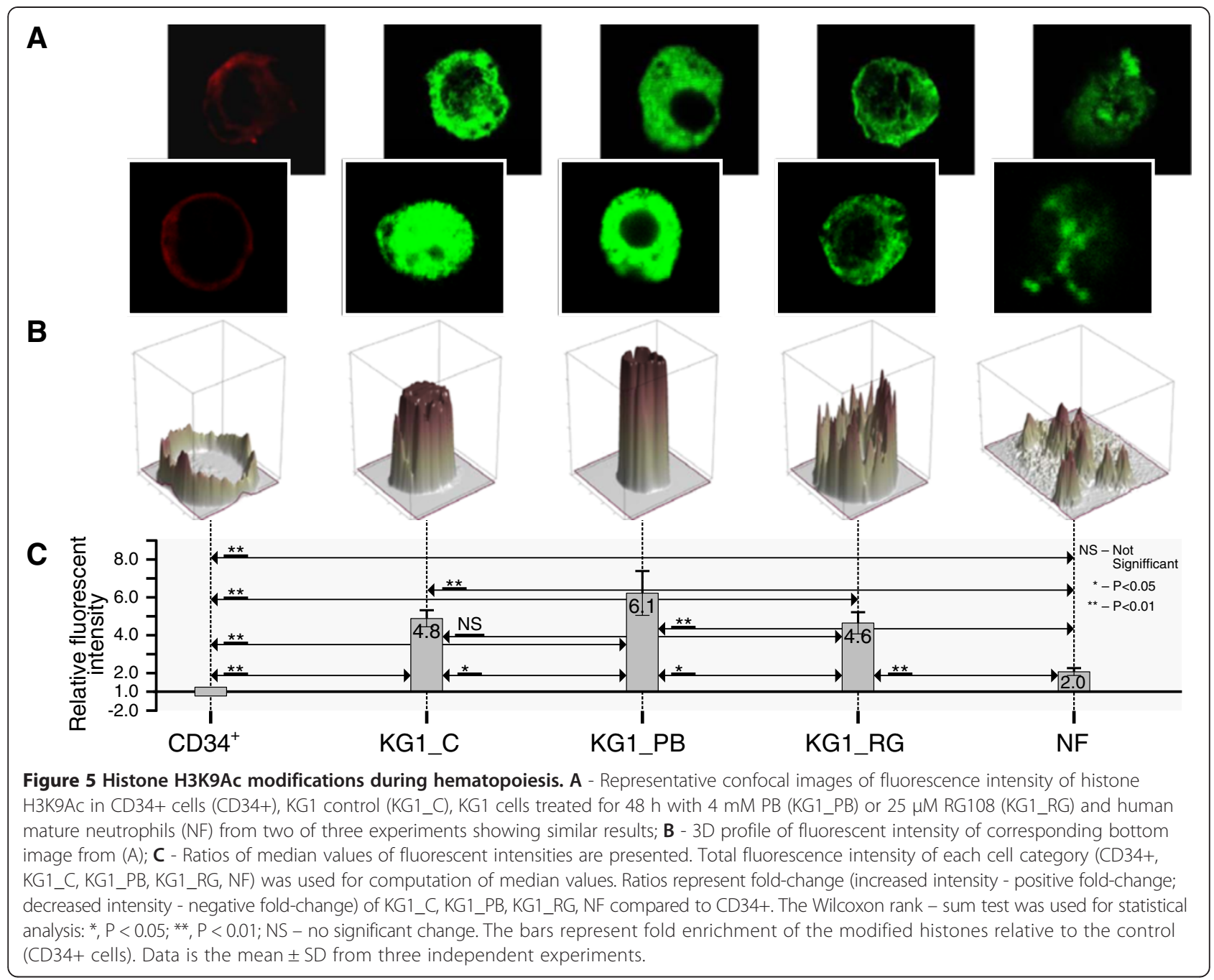

The upper layer was collected, centrifuged at $300 \times \mathrm{g}$ for $10 \mathrm{~min}$ at $4^{\circ} \mathrm{C}$, the pellet suspended in cold Krebs-RingerGlucose (KRG) solution without $\mathrm{Ca}^{2+}$ and slowly transferred onto a Lymphoprep (Axis Shield, Oslo, Norway) gradient. After centrifugation at $450 \times \mathrm{g}$ for $30 \mathrm{~min}$ at $4{ }^{\circ} \mathrm{C}$, cells from the mononuclear layer were collected, diluted and washed in cold KRG without $\mathrm{Ca}^{2+}$ by centrifugation at $200 \times \mathrm{g}$ for $10 \mathrm{~min}$ at $4^{\circ} \mathrm{C}$. Pelleted erythrocytes were lysed in cold water for $30 \mathrm{sec}$ following a brief addition of $1: 3 \mathrm{vol}$ of $3.4 \% \mathrm{NaCl}$ and 0.55 vol of KRG without $\mathrm{Ca}^{2+}$. Mononuclear cells were pelleted, resuspended and washed twice in PBS by centrifugation at $220 \times \mathrm{g}$ for $10 \mathrm{~min}$ at $4^{\circ} \mathrm{C}$.

\section{Ethics statement}

The study was conducted in accordance with the Declaration of Helsinki. Human blood was collected at the blood bank at Linkoping University Hospital by employees at the blood bank division and written consent for research use of donated blood was obtained from all donors. Since blood donation is classified as negligible risk to the donors and since only anonymized samples were delivered to the researchers, the research did not require ethical approval according to paragraph 4 of the Swedish Law (2003: 460; http://www.lagboken.se/ dokument/Lagar-och-forordningar/4060/Lag-2003_460-ometikprovning-av-forskning-som-avser-manniskor?id=64991) on Ethical Conduct in Human Research.

\section{Isolation of CD34+ cells}

CD34+ cells were isolated with the CD34 MicroBead Kit according to the manufacturer's instructions (Miltenyi Biotec, Germany). Briefly, mononuclear cells were diluted with Isolation buffer containing PBS supplemented with $0.5 \%$ BSA and $2 \mathrm{mM}$ EDTA (1:2), and cell clumps were removed by filtering through $30 \mu \mathrm{M}$ nylon mesh (Miltenyi Biotec, Germany). Then cells were counted and resuspended in Isolation buffer for the up to $10^{8}$ total cells. Cells were labeled by adding FcR Blocking reagent and CD34 MicroBeads for $30 \mathrm{~min}$ at $4-8^{\circ} \mathrm{C}$. After 


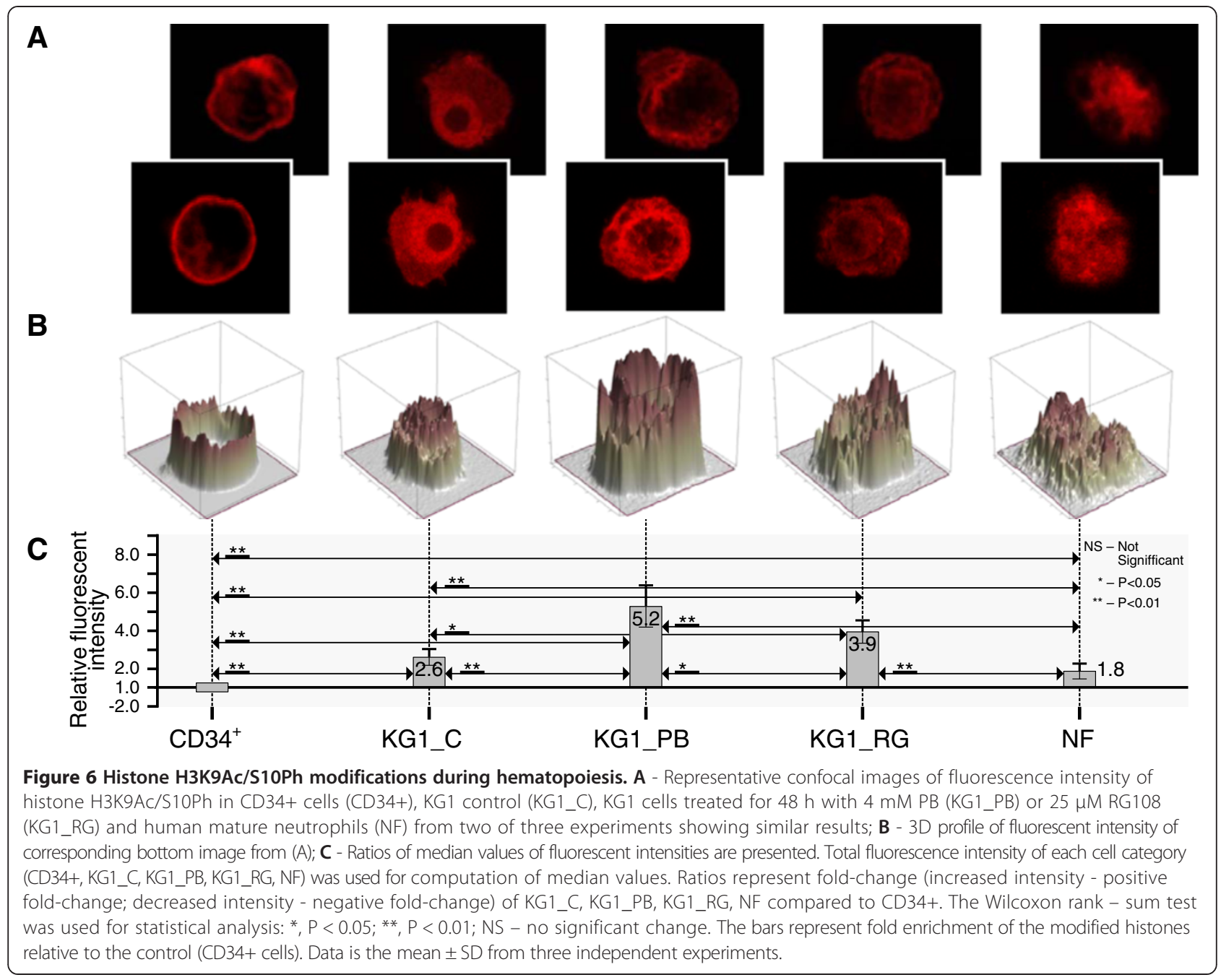

centrifugation at $200 \times \mathrm{g}$ for $10 \mathrm{~min}$ at $4^{\circ} \mathrm{C}$, cell suspension was applied onto the LS column, unlabelled cell fraction in the effluent was removed and labeled cells were separated using MidiMACs separator. The purity of isolated CD34+ cells was evaluated by flow cytometry and fluorescence microscopy. Flow cytometric analysis by the use of Becton-Dickinson FACS (Becton-Dickinson FACS Calibur, San Jose, CA) demonstrated a purity of $>65 \%$ CD34+ cells. For the analysis of histones, the nuclear fraction was isolated from 2.5-3 × $10^{6} \mathrm{CD} 34+$ cells; genomic DNA was prepared from about $4 \times 10^{7}$ CD34+ cells.

\section{Isolation of neutrophils from healthy human blood}

Defibrinated fresh blood was carefully laid on Polymorphprep $^{\text {Ts }}$ (Nycomed Pharma AS, Oslo, Norway): Lymphoprep gradient (4:1) and centrifuged in swing-out centrifuge at $600 \times \mathrm{g}$ for $45 \mathrm{~min}$ at room temperature. The uppermost layers down to the granulocyte band were aspirated, and the very diffuse band with granulocytes (neutrophils) collected and diluted with PBS, $\mathrm{pH}$ 7.3. After centrifugation at $600 \times \mathrm{g}$ for $10 \mathrm{~min}$ at room temperature, erythrocytes from the pellet were removed by lysis in water as described above, the pellet of neutrophils resuspended in PBS.

\section{Histone isolation and analysis}

Cells $\left(5 \times 10^{6}\right.$ to $\left.10^{7}\right)$ were harvested by centrifugation at $500 \times \mathrm{g}$ for $6 \mathrm{~min}$, washed twice in ice cold PBS, suspended in Nuclei EZ lysis buffer (Sigma, St. Louis, MO) and nuclei isolated as described by manufacture. For preparation of histones, isolated nuclei were suspended in 5 vol. of $0.4 \mathrm{~N} \mathrm{H}_{2} \mathrm{SO}_{4}$ by stirring and incubated overnight at $0^{\circ} \mathrm{C}$. The supernatant was collected by centrifugation at $15,000 \mathrm{xg}$ for $10 \mathrm{~min}$ at $+2^{\circ} \mathrm{C}$ and the sediment was extracted once more. After centrifugation, both extracts were combined and histones were precipitated by adding 5 vol. of ethanol at $-20^{\circ} \mathrm{C}$ overnight. The precipitated histones 


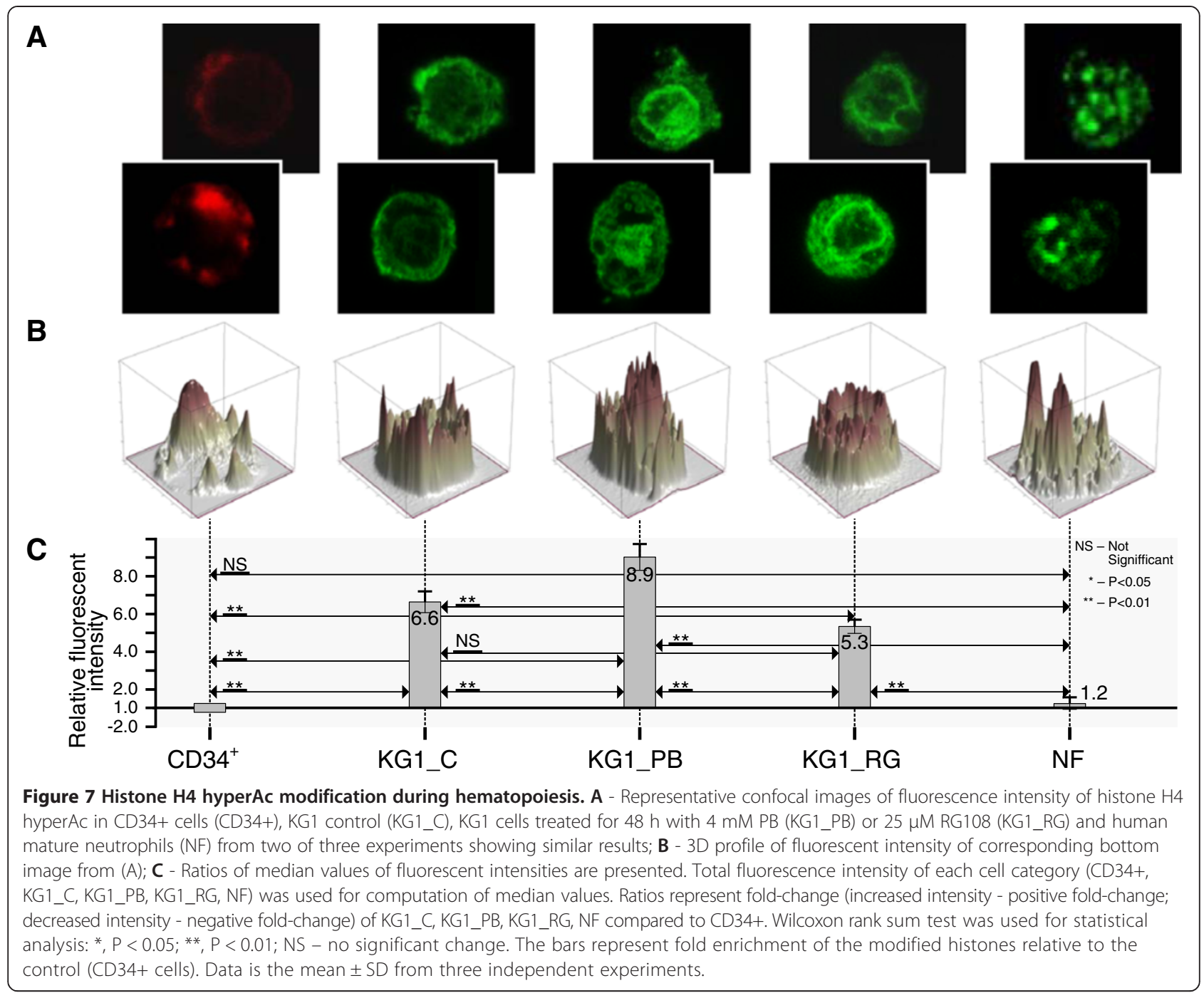

were collected by centrifugation, washed several times with ethanol and stored at $-20^{\circ} \mathrm{C}$ until analysis.

Histones $(5 \mu \mathrm{g})$ were dissolved in a buffer containing $0.9 \mathrm{M}$ acetic acid, 10\% glycerol, 6.25 $\mathrm{M}$ urea and 5\% $\beta$-mercaptoethanol, and separated on $15 \%$ polyacrylamide gel containing $6 \mathrm{M}$ urea and $0.9 \mathrm{M}$ acetic acid by using $0.9 \mathrm{M}$ acetic acid as a buffer [37]. Histones were detected in AUT system (15\% polyacrylamide, $6 \mathrm{M}$ urea, $4 \mathrm{mM}$ Triton $\mathrm{X}-100$ and $0.9 \mathrm{M}$ acetic acid) [38]. After electrophoresis, the gel was stained with Brilliant Blue G-colloidal (Sigma, St. Louis, MO) or blots were probed with primary antibodies against total histone H3 (Abcam, Cambridge PLC.) and secondary antibodies, or fractionated in SDS/PAGE system. Immunoreactive bands were detected by enhanced chemiluminescence according to the manufacturer's instruction (Western Bright ECL, Advansta Corporation, Menlo Park, CA).

\section{Bisulfite modification and methylation-specific PCR}

The methylation status of gene promoters was determined with the EZ DNA methylation-Direct ${ }^{\mathrm{Tm}}$ kit (Zymo Research, Irvine, CA). Briefly, cells $\left(1-9 \times 10^{5}\right)$ were digested in the reaction mixture with proteinase $\mathrm{K}$ at $50^{\circ} \mathrm{C}$ for $20 \mathrm{~min}$. Bisulfite conversion of DNA was performed according to the manufacturer's instruction. Thus after conversion of all unmethylated cytosines to uracils, the modified DNA was purified using a Zymo$\operatorname{Spin}^{\mathrm{TM}}$ IC column and used for PCR amplification. The primers, forward (F) or reverse (R), for methylated (M) and unmethylated (U) promoters of the target genes were as follows: E-cadherin (MF) 5' - CAA TTA GCG GTA CGG GGG GC-3', E-cadherin (MR) 5'-CGA AAA CAA ACG CCG AAT ACG-3'; E-cadherin (UF) 5' -TTA GTT AAT TAG TGG TAT GGG GGG TGG- 3'; $E$ cadherin (UR) 5' -ACC AAA CAA AAA CAA ACA CCA AAT ACA-3'; p15 (MF), 5'-GCG TTC GTA TTT TGC 
GGT T-3'; $p 15$ (MR) 5' -CGT ACA ATA ACC GAA CGA CCG A-3'; 15 (UF), 5' -TGT GAT GTG TTT GTA TTT TGT GGT T-3'; p15 (UR), 5' -CCA TAC AAT AAC CAA ACA ACC AA-3'. p16 (MF), 5'-TTA TTA GAG GGT GGG GCG GAT CGC -3'; p16 (MR) 5'-GAC CCC GAA CCG CGA CCG TAA-3'; $p 16$ (UF), 5' -TTA TTA GAG GCT GGG GTG GAT TGT-3'; p16 (UR), 5' -CAA CCC CAA ACC ACA ACC ATA A-3'. RAR $\beta$ (MF), 5'-GGA TTG GGA TGT CGA GAA C-3'; RAR $\beta$ (MR) 5'-TAC AAA AAA CCT TCC GAA TAC G-3'; RAR $\beta$ (UF), 5' AGG ATT GGG ATG TTG AGA ATG-3'; RAR $\beta$ (UR), 5' -TTA CAA AAA ACC TTC CAA ATA CA-3'. Cycling conditions: $95^{\circ} \mathrm{C}$ for $5 \mathrm{~min}, 40$ cycles $\left(95^{\circ} \mathrm{C}\right.$ for $30 \mathrm{~s}$, annealing temperature $66^{\circ} \mathrm{C}$ (for E-cadherin and $p 15$ Met), $62^{\circ} \mathrm{C}$ (for E-cadherin Unmet and $p 16 \mathrm{Met}$ ), $57^{\circ} \mathrm{C}$ (for $p 15$ and $p 16$ Unmet, $R A R \beta$ ) for $30 \mathrm{~s}, 72^{\circ} \mathrm{C}$ for $30 \mathrm{~s}$ ), $72^{\circ} \mathrm{C}$ for $10 \mathrm{~min}$. The products were electrophoresed on $3 \%$ agarose gel, stained with ethidium bromide, and photographed. The product sizes were as follows: for $p 15,150 \mathrm{bp}$; for $E$ cadherin, $170 \mathrm{bp}, p 16,150 \mathrm{bp}, R A R \beta 93 \mathrm{bp}$. The methylation status of DNA was determined in duplicate samples of three independent experiments.

\section{Immunofluorescence labeling and confocal laser scanning microscopy (CLSM) of cells}

Cover-slips with the captured cells were rinsed three times in phosphate buffer (PBS, pH 7.6) and fixed for $15 \mathrm{~min}$ in phosphate buffer supplemented with $3.3 \%(\mathrm{w} / \mathrm{v})$ paraformaldehyde. Then cells were rinsed three times in PBS, pH 7.6, and permeabilized with $3.3 \%$ Triton $\mathrm{X}-100$ for $15 \mathrm{~min}$. The cells were blocked with phosphate buffer containing $5 \%(\mathrm{v} / \mathrm{v})$ goat serum (DAKO) for $60 \mathrm{~min}$ at room temperature. Then, the cover-slips were rinsed and incubated with the indicated primary antibodies against H3K4Me3, H3K9Ac, H3K9Ac/ S10Ph (Upstate Biotechnology Inc., Lake Placid, NY) and anti-cd34 ${ }^{+}$-FITC (Miltenyi Biotec Inc., Bergisch Gladbach, Germany) for $90 \mathrm{~min}$ at $37^{\circ} \mathrm{C}$ and three times rinsed with PBS, pH 7.6. Finally, the cover-slips that needed were incubated with secondary antibodies, i.e. Alexa 564-coupled goat anti-rabbit or Alexa 488-coupled goat anti-rabbit Fab fragments (Molecular Probes, Eugene, OR) at a concentration $15 \mu \mathrm{g} / \mathrm{ml}$ for visualization.

For confocal imaging, we used a Bio-Rad Radiance 2100 and Radiance 2000MP (Carl Zeiss, Jena, Germany). Images were taken in sequence after inserting the signal enhancing lenses by activating channel 1 (blue); not used: Mai-Tai laser (815 nm), with dichroic beam -splitter 500DCLPXR, blocking filter BGG22 and emission filter D488/10; channel 2 (green): Argon laser (488 nm), no blocking filter and emission filter HQ545/40; and channel 3 (red): Argon laser (488 and $514 \mathrm{~nm}$ ), no blocking filter and the emission filter E600 LP. The microscope was a Nikon Eclipse TE2000U (Tokyo, Japan), equipped with PlanApo DicH x60 oil immersion objective (NA 1.40).
For visualization of modified histones in CD34+, KG1 and NF three independent biological experiments were carried out. Through observation of the samples around $70-80 \%$ of the cells displayed a positive marking of modified histones. Images of representative 4-9 cells from each experiment for each histone modification were taken and summarized in the graphs of the Figures 4, 5, 6 and 7 .

\section{Statistical analysis}

Data provided by fluorescence image analysis were not normally distributed, so Wilcoxon rank sum test was used as nonparametric alternative to the two-sample t-test used for independent samples. The Wilcoxon rank - sum test allows a hypothesis test of the equality of two samples medians. ${ }^{*} \mathrm{P}<0.05$ and ${ }^{* *} \mathrm{P}<0.01$ were considered as statistically significant, and NS describes no significant change. The bar graphs in Figures 4, 5, 6 and 7 represent fold- enrichment of the modified histones relative to the control (CD34+ cells). Data is the mean \pm SD from three independent experiments.

\section{Image analysis}

In this research, suit of custom image analysis functions were used. Functions have been implemented in Matlab ${ }^{\text {тm }}$ environment (The MathWorks, Natick MA, USA) and were built based on our prototype for 2-Dimensional Electrophoresis gel image analysis [39].

The developed tools were used for fluorescent image analysis, i.e. image preprocessing, segmentation, fluorescent intensity data mining and statistical data analysis. During image preprocessing Gaussian image smoothing is performed for noise reduction. Purpose of segmentation is to acquire spot boundary that delineates cell area from background and other cells. Segmented cell area is used as region of interest (ROI) for spot volume calculations. During segmentation, all available cell layers, that were acquired from microscope, are used. Key tools in segmentation algorithm are symmetrical feature detector and Watershed transformation. Symmetrical feature detector generates map of second order symmetries by the use of the Johansson method [40]. Watershed transformation is used for splitting of symmetry map. After isolation of individual cells, total fluorescent intensity of each cell was obtained.

The protein quantity $V$ in a cell is defined as the total fluorescent intensity in a segmented region of corresponding cell. The total intensity of an object is the sum of the intensities of all the pixels that make up the object:

$$
V=\sum_{(x, y) \in \operatorname{cell}} I(x, y)
$$

After quantifying all cells, median values of total fluorescence intensities of each cell grouped by class were computed. The ratios between median values represent 
fold-change in protein expression. An increase of fluorescent intensity yields a positive fold-change and a decrease, accordingly a negative fold-change. Wilcoxon's rank sum test was used to evaluate statistically significant changes.

\section{Abbreviations}

AML: Acute myelogenous leukemia; CpG: Cytosine-phosphate-guanine; DNMT: DNA methyltransferase; DNMTI: DNA methyltransferase inhibitor; HDAC: Histone deacetylase; HDACl: Histone deacetylase inhibitor;

PB: Sodium-4-phenylbutyrate.

\section{Competing interests}

The authors declare that they have no competing interests.

\section{Authors' contributions}

RN designed the project, oversaw data generation and wrote the manuscript. WB carried out the gene methylation/demethylation experiments, performed confocal scanning imaging. DM carried out analysis of confocal images data with computer- assisted methods and data interpretation. GT performed histone isolation, fractionation and analysis. JS isolated CD34+ cells and mature neutrophils from human peripheral blood and prepared KG1 cells for analyses. DN has made substantial contribution to conception and design of image analysis and data acquisition by using computer assisted methods. KEM participated in the experiments with confocal microscopy, the experimental design of the study and revising of the manuscript. All authors read and approved the final manuscript for publication.

\section{Acknowledgements}

This work was supported by a grant (No. LIG-06/2012) from the Research Council of Lithuania, Swedish Institute Visby Program (Grant No. 00879/ 2009), Swedish Research Council (Project Nos. 2007-3483, 2009-6649 and 2010-3045), a EU Marie Curie Postdoctoral fellowship through Forum Scientium, Linköping University (Dr. Veronika Borutinskaite) and a European Union Structural Funds project "Postdoctoral Fellowship Implementation in Lithuania" through Vilnius University (Dr. Dalius Matuzevičius).

\section{Author details}

'Department of Molecular Cell Biology, Institute of Biochemistry, Vilnius University, LT-08662 Vilnius, Lithuania. ${ }^{2}$ Department of Chemistry and Bioengineering, Faculty of Fundamental Sciences, Vilnius Gediminas Technical University, LT-10223 Vilnius, Lithuania. ${ }^{3}$ Department of General Psychology, Faculty of Philosophy, Vilnius University, Universiteto st. 9/1, LT-01513 Vilnius, Lithuania. ${ }^{4}$ Electronic Systems Department, Faculty of Electronics, Vilnius Gediminas Technical University, Naugarduko 41-422, LT-03227 Vilnius, Lithuania. ${ }^{5}$ Division of Medical Microbiology, Department of Clinical and Experimental Medicine, Linkoping University, SE-581 85 Linkoping, Sweden.

Received: 24 May 2013 Accepted: 11 January 2014

Published: 20 January 2014

\section{References}

1. Choo KB: Epigenetics in disease and cancer. Malays J Pathol 2011, 33:61-70.

2. McDevitt MA: Clinical applications of epigenetic markers and epigenetic profiling in myeloid malignancies. Semin Oncol 2012, 39:109-122.

3. Melnick AM: Epigenetics in AML. Best Pract Res Clin Haematol 2010, 23:463-468

4. Griffiths EA, Gore SD: DNA methyltransferase and histone deacetylase inhibitors in the treatment of myelodysplastic syndromes. Semin Hematol 2008, 45:23-30.

5. Gozzini A, Santini V: Butyrates and decitabine cooperate to induce histone acetylation and granulocytic maturation of $\mathrm{t}(8 ; 21)$ acute myeloid leukemia blasts. Ann Hematol 2005, 84(Suppl 1):54-60.

6. Poetsch AR, Plass C: Transcriptional regulation by DNA methylation. Cancer Treat Rev 2011, 37:S8-S12.

7. Hopfer O, Komor M, Koehler IS, Freitag C, Schulze M, Hoelzer D, Thiel E, Hofmann WK: Aberrant promotor methylation in MDS hematopoietic cells during in vitro lineage specific differentiation is differently associated with DNMT isoforms. Leuk Res 2009, 33:434-442.
8. Oki Y, Issa JP: Epigenetic mechanisms in AML - a target for therapy. Cancer Treat Res 2010, 145:19-40.

9. Galm O, Wilop S, Lüders C, Jost E, Gehbauer G, Herman JG, Osieka R: Clinical implications of aberrant DNA methylation patterns in acute myelogenous leukemia. Ann Hematol 2005, 84(Suppl 1):39-46.

10. Zhang Y, Rohde C, Tierling S, Jurkowski TP, Bock C, Santacruz D, Ragozin S, Reinhardt R, Groth M, Walter J, Jeltsch A: DNA methylation analysis of chromosome 21 gene promoters at single base pair and single allele resolution. PLoS Genet 2009, 5:e1000438.

11. Meissner A, Mikkelsen TS, Gu H, Wernig M, Hanna J, Sivachenko A, Zhang X, Bernstein BE, Nusbaum C, Jaffe DB, Gnirke A, Jaenisch R, Lander ES: Genome-scale DNA methylation maps of pluripotent and differentiated cells. Nature 2008, 454:766-770

12. Rice $K L$, Hormaeche I, Licht JD: Epigenetic regulation of normal and malignant hematopoiesis. Oncogene 2007, 26:6697-6714.

13. Kusy S, Cividin M, Sorel N, Brizard F, Guilhot F, Brizard A, Larsen C, Roche J: p14ARF, p15INK4b, and p16INK4a methylation status in chronic myelogenous leukemia. Blood 2003, 101:374-375.

14. Kusy S, Larsen CJ, Roche J: p14ARF, p15INK4b and p16INK4a methylation status in chronic myelogenous leukemia. Leuk Lymphoma 2004, 45:1989-1994.

15. Mizuno S, Chijiwa T, Okamura T, Akashi K, Fukumaki Y, Niho Y, Sasaki H: Expression of DNA methyltransferases DNMT1, 3A, and 3B in normal hematopoiesis and in acute and chronic myelogenous leukemia. Blood 2001, 97:1172-1179.

16. Savickiene J, Treigyte G, Jonusiene V, Bruzaite R, Borutinskaite W, Navakauskiene R: Epigenetic changes by zebularine leading to enhanced differentiation of human promyelocytic leukemia NB4 and KG1 cells. Mol Cell Biochem 2012, 359:245-261.

17. Savickiene J, Treigyte G, Jazdauskaite A, Borutinskaite W, Navakauskiene R: DNA methyltransferase inhibitor RG108 and histone deacetylase inhibitors cooperate to enhance NB4 cell differentiation and E-cadherin re-expression by chromatin remodeling. Cell Biol Int 2012, 36:1067-1078.

18. Savickiene J, Treigyte G, Borutinskaite W, Navakauskiene R: Antileukemic activity of combined epigenetic agents, DNMT inhibitors zebularine and RG108 with HDAC inhibitors, against promyelocytic leukemia HL-60 cells. CMBL 2012, 17:501-525.

19. Savickiene J, Treigyte G, Magnusson K-E, Navakauskiene R: Response of retinoic acid-resistant KG1 cells to combination of retinoic acid with diverse histone deacetylase inhibitors. Ann NY Acad Sci 2009, 1171:321-333.

20. Armeanu S, Bühring HJ, Reuss-Borst M, Müller CA, Klein G: E-cadherin is functionally involved in the maturation of the erythroid lineage. J Cell Biol 1995, 131:243-249.

21. Turel KR, Rao SG: Expression of the cell adhesion molecule E-cadherin by the human bone marrow stromal cells and its probable role in CD34(+) stem cell adhesion. Cell Biol Int 1998, 22:641-648.

22. Corn PG, Kuerbitz SJ, van Noesel MM, Esteller M, Compitello N, Baylin SB, Herman JG: Transcriptional silencing of the p73 gene in acute lymphoblastic leukemia and Burkitt's lymphoma is associated with 5' CpG island methylation. Cancer Res 1999, 59:3352-3356.

23. Fazi F, Travaglini L, Carotti D, Palitti F, Diverio D, Alcalay M, McNamara S, Miller WH Jr, Lo Coco F, Pelicci PG, Nervi C: Retinoic acid targets DNA-methyltransferases and histone deacetylases during APL blast differentiation in vitro and in vivo. Oncogene 2005, 24:1820-1830.

24. Fazi F, Zardo G, Gelmetti V, Travaglini L, Ciolfi A, Di Croce L, Rosa A, Bozzoni I, Grignani F, Lo-Coco F, Pelicci PG, Nevvi C: Heterochromatic gene repression of the retinoic acid pathway in acute myeloid leukemia. Blood 2007, 109:4432-4440.

25. de The H, Marchio A, Tiollais P, Dejean A: Differential expression and ligand regulation of the retinoic acid receptor alpha and beta genes. EMBO J 1989, 8:429-433.

26. Sirchia SM, Ferguson AT, Sironi E, Subramanyan S, Orlandi R, Sukumar S, Sacchi N: Evidence of epigenetic changes affecting the chromatin state of the retinoic acid receptor beta2 promoter in breast cancer cells. Oncogene 2000, 19:1556-1563.

27. Mongan NP, Gudas LJ: Valproic acid, in combination with all-trans retinoic acid and 5-aza-2'-deoxycytidine, restores expression of silenced RARbeta2 in breast cancer cells. Mol Cancer Ther 2005, 4:477-486.

28. Godde JS, Ura K: Dynamic alterations of linker histone variants during development. Int J Dev Biol 2009, 53:215-224.

29. Lord KA, Hoffman-Liebermann B, Liebermann DA: Complexity of the immediate early response of myeloid cells to terminal differentiation 
and growth arrest includes ICAM-1, Jun-B and histone variants. Oncogene 1990, 5:387-396.

30. Terme JM, Sesé B, Millán-Ariño L, Mayor R, Izpisúa Belmonte JC, Barrero MJ, Jordan A: Histone $\mathrm{H} 1$ variants are differentially expressed and incorporated into chromatin during differentiation and reprogramming to pluripotency. J Biol Chem 2011, 286:35347-35357.

31. Barrero MJ, Sese B, Marti M, Izpisua Belmonte JC: Macro histone variants are critical for the differentiation of human pluripotent cells. J Biol Chem 2013, 288:16110-16116.

32. Ahmad $\mathrm{K}$, Henikoff $\mathrm{S}$ : The histone variant $\mathrm{H} 3.3$ marks active chromatin by replication-independent nucleosome assembly. Mol Cell 2002, 9:1191-1200.

33. Jin C, Felsenfeld G: Distribution of histone H3.3 in hematopoietic cell lineages. Proc Natl Acad Sci USA 2006, 103:574-579.

34. Merzvinskyte R, Treigyte G, Savickiene J, Magnusson KE, Navakauskiene R: Effects of histone deacetylase inhibitors, sodium phenyl butyrate and vitamin B3, in combination with retinoic acid on granulocytic differentiation of human promyelocytic leukemia HL-60 cells. Ann NY Acad Sci 2006, 1091:356-367.

35. Müller-Tidow C, Klein HU, Hascher A, Isken F, Tickenbrock L, Thoennissen N, Agrawal-Singh S, Tschanter P, Disselhoff C, Wang Y, Becker A, Thiede C, Ehninger G, Zur Stadt U, Koschmieder S, Seidl M, Müller FU, Schmitz W, Schlenke P, McClelland M, Berdel WE, Dugas M, Serve H, Study Alliance Leukemia: Profiling of histone H3 lysine 9 trimethylation levels predicts transcription factor activity and survival in acute myeloid leukemia. Blood 2010, 116:3564-3571.

36. Paul TA, Bies J, Small D, Wolff $L$ : Signatures of polycomb repression and reduced H3K4 trimethylation are associated with p15INK4b DNA methylation in AML. Blood 2010, 115:3098-3108.

37. Hurley CK: Electrophoresis of histones: a modified Panyim and Chalkley system for slab gels. Anal Biochem 1977, 80:624-626.

38. Zalensky AO, Siino JS, Gineitis AA, Zalenskaya IA, Tomilin NV, Yau P, Bradbury EM: Human testis/sperm-specific histone H2B (hTSH2B). Molecular cloning and characterization. J Biol Chem 2002, 277:43474-43480.

39. Pivoriūnas A, Surovas A, Borutinskaitè V, Matuzevičius D, Treigyte G, Savickiené J, Tunaitis V, Aldonyte R, Jarmalavičiūte A, Suriakaite K, Liutkevičius E, Venalis A, Navakauskas D, Navakauskiené R, Magnusson KE: Proteomic analysis of stromal cells derived from the dental pulp of human exfoliated deciduous teeth. Stem Cells Dev 2010, 19:1081-1093.

40. Johansson B: Low level operations and learning in computer vision. In Dissertation No. 912. Sweden: Linköping University; 2004.

doi:10.1186/1471-2121-15-4

Cite this article as: Navakauskienè et al: Epigenetic changes during hematopoietic cell granulocytic differentiation - comparative analysis of primary CD34+ cells, KG1 myeloid cells and mature neutrophils. BMC Cell Biology 2014 15:4.

\section{Submit your next manuscript to BioMed Central and take full advantage of:}

- Convenient online submission

- Thorough peer review

- No space constraints or color figure charges

- Immediate publication on acceptance

- Inclusion in PubMed, CAS, Scopus and Google Scholar

- Research which is freely available for redistribution 